\title{
IMPLEMENTASI ARSITEKTUR BERKELANJUTAN Pada Strategi Perancangan Rusunawa di Surakarta
}

\author{
Khrisma Ananditya $^{1^{*}}$, Made Suastika ${ }^{2}$, Amin Sumadyo ${ }^{3}$ \\ Program Studi Arsitektur, Fakultas Teknik, Universitas Sebelas Maret ${ }^{1}$ \\ Email: khrisma.ldp5@gmail.com * \\ Program Studi Arsitektur, Fakultas Teknik, Universitas Sebelas Maret ${ }^{2}$ \\ Program Studi Arsitektur, Fakultas Teknik, Universitas Sebelas Maret ${ }^{3}$
}

\begin{abstract}
Based on the description from The Head of UPTD Rumah Sewa in Surakarta on February 2017, there are about 500 heads of households have registered as Rusunawa (lower-middle class rental apartment) residents, who still on the waiting list, due to limited number of residential units built by the government. It becomes the main reason of the emergence of idea, to build the new Rusunawa in this city. Sustainable architecture is chosen as the design approach of the project, to achieve an efficient design that fulfill the needs of its inhabitants without neglecting environmental sustainability, the main aspects in this theory are described as follows : economic aspect contains the effort of economizing, social aspect contains fulfillment of basic needs of human occupancy \& comfort of the inhabitants, and environmental aspect contains effort of preserving environment.
\end{abstract}

Keywords : housing, apartment, rental apartment, sustainable architecture

\section{PENDAHULUAN}

\section{Latar Belakang}

Rumah susun adalah bangunan gedung bertingkat yang dibangun dalam suatu lingkungan, yang terbagi dalam bagian-bagian yang distrukturkan secara fungsional, baik dalam arah horizontal maupun vertikal. (UU No. 20 Tahun 2011). Rumah Susun Sederhana Sewa (Rusunawa) merupakan salah satu macam rumah susun, dimana status penguasaannya dengan sistem sewa (bukan hak milik).

Kota Surakarta adalah salah satu kota besar di Jawa Tengah, Indonesia, dengan luas wilayah 44,04 km2, terdiri dari 5 kecamatan, 51 kelurahan, 604 RW, dan 2.714 RT. Di kota ini, ada 11 rumah susun telah dibangun di Kota Surakarta, dan 2 rumah susun sudah direncanakan di tahun 2016 yang mungkin segera direalisasikan di tahun 2017. Informasi terakhir, terdapat sekitar $500 \mathrm{KK}$ telah mendaftar sebagai calon penghuni rusunawa, yang saat ini masih berada dalam daftar tunggu, karena keterbatasan jumlah unit hunian yang sudah dibangun. Para pendaftar tersebut banyak yang tergolong sebagai masyarakat berpenghasilan rendah, yang bekerja pada sektor informal, dan belum memiliki rumah tinggal pribadi, sesuai kriteria / persyaratan penghuni rusunawa, yang sudah ditetapkan oleh pemerintah Kota Surakarta.

Di sisi lain, masih nampak adanya fenomena masyarakat tinggal di permukiman kumuh di kota tersebut. Adanya rusunawa baru juga dapat menjadi alternatif tempat tinggal baru, terutama bagi mereka yang sebelumnya kurang aman dan nyaman tinggal di rumah lama mereka. Selain alasan di atas, tidak menutup kemungkinan pula bila rusunawa yang direncanakan, menjadi alternatif tempat tinggal bagi masyarakat ekonomi kelas menengah ke bawah, diluar pendaftar yang tercatat oleh pemerintah tersebut.

\section{Tinjauan Teori}

Desain yang berkelanjutan (sustainable design) adalah desain yang menciptakan sebuah solusi yang menjawab tantangan ekonomi (economy), sosial (community), dan lingkungan (environment) pada proyek secara simultan, dan solusinya digerakkan oleh energi yang berkelanjutan (Williams, 2007). 


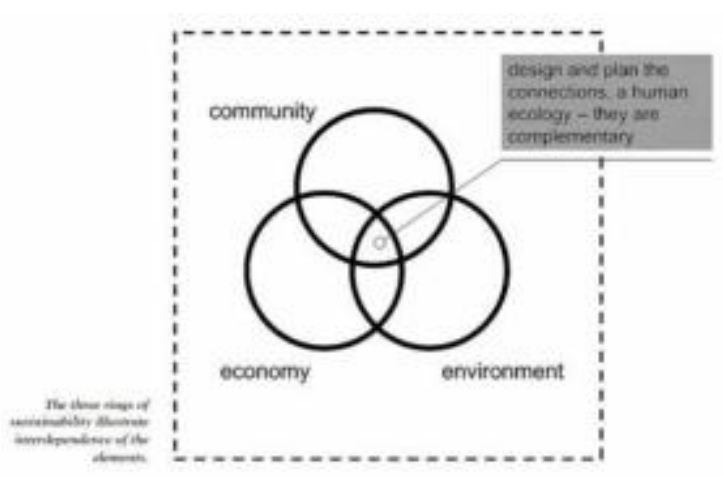

Gambar 1. Hubungan gambaran tentang peran sustainable architecture dan kaitannya dengan bidang ekonomi, sosial, dan lingkungan (Williams, Daniel E (2007 : 13))

\section{Regulasi}

Persyaratan teknis pembangunan rumah susun menggunakan Peraturan Menteri Pekerjaan Umum No. 60/PRT/1992 sebagai referensi.

\section{METODE}

(1) Mengidentifikasi prinsip dasar teori Arsitektur Berkelanjutan sebagai pendekatan desain; (2) Menurunkan prinsip dasar teori Arsitektur Berkelanjutan ke dalam beberapa poin penting, yang disesuaikan dengan konteks dan orientasi hasil akhir yang diharapkan, yaitu efisiensi (keseimbangan) keberlanjutan hidup penghuni (sosial \& ekonomi) dan keberlanjutan lingkungan meliputi : (1) Aspek ekonomi (upaya keberlanjutan kegiatan ekonomi penghuni, dan upaya penghematan (penghematan pengeluaran penghuni selama tinggal dalam obyek rancang bangun (prioritas penghuni yang termasuk dalam masyarakat ekonomi kelas menengah ke bawah, dengan segala keterbatasannya)) dan penghematan biaya konstruksi dan perawatan bangunan), (2) Aspek sosial (ketersediaan fasilitas dasar (air bersih layak konsumsi \& sanitasi dan listrik (terutama penerangan malam hari)), kebutuhan ruang yang mewadahi aktivitas yang penting / perlu diwujudkan dalam obyek rancang bangun (aktivitas dasar hunian) terpenuhi, memenuhi standar keamanan / keselamatan dan kesehatan, dan memenuhi standar kenyamanan menurut asumsi pribadi (wawasan, pengalaman, pengembangan logika) yang masih mungkin untuk diupayakan, dengan batasan menghindari kemungkinan penghuni menjadi enggan untuk tinggal di dalam rusun fleksibilitas), dan (3) Aspek lingkungan (merespon iklim, meminimalisir penggunaan sumber daya alam (energi \& material) yang sulit, atau tak terbarukan, atau tidak dapat di-daur ulang, dan meminimalisir pencemaran lingkungan (konservasi air dan manajemen limbah / sampah); dan (3) Mengimplementasikan poin-poin di atas, sebagai orientasi dari dasar pertimbangan dalam alur perancangan obyek rancang bangun, yang memperhatikan konteks (user dan kondisi site \& lingkungan) dengan batasan-batasan tertentu, meliputi : pemilihan site; pembuatan konsep dan desain peruangan \& sirkulasi, struktur \& material, dan sistem utilitas (sistem jaringan air bersih, sistem jaringan sanitasi \& drainase, sistem elektrikal, sistem persampahan, sistem proteksi kebakaran, dan sistem penangkal petir).

\section{HASIL DAN PEMBAHASAN}

\section{Analisis \& konsep lokasi site}

Dasar pertimbangan : Lahan kosong atau tidak produktif, yang mungkin untuk dibangun (kriteria kemungkinan untuk dibangun mencakup pertimbangan-pertimbangan lain yang disebutkan di bawah ini), yang cukup luas (lahan potensial terluas yang ada di dalam kota Surakarta, yang mampu dicari oleh perancang); Rencana pembangunan rusunawa oleh pemerintah Kota Surakarta; Kesesuaian dengan RTRW Kota Surakarta; Faktor ketidaknyamanan yang mungkin muncul : resiko bencana (genangan / banjir, longsor), polusi (udara / bau / asap, suara (bising), sampah (kumuh)), gangguan / ancaman (hama, kejahatan), dan faktor ketidaknyamanan lainnya (mistis); Sarana \& prasarana yang mendukung : ketersediaan sumber air bersih, ketersediaan jaringan listrik, akses transportasi (jalan), jarak dan kemudahan pencapaian terhadap fasilitas sosial / umum (pelayanan untuk mencukupi kebutuhan sehari-hari, pelayanan kesehatan, fasilitas pendidikan 
dasar, tempat ibadah, pelayanan transportasi umum), sistem sanitasi \& drainase lingkungan, sistem penanganan sampah, dan ketersediaan jaringan komunikasi (sinyal telepon); Biaya pembebasan dan persiapan lahan untuk pembangunan; dan Potensi lain yang mungkin mendukung (menjadi nilai tambah) : potensi ekonomi / usaha, dan potensi view. Lokasi site terpilih berada di Kelurahan Mojosongo, Kecamatan Jebres, Surakarta, Jateng, Indonesia (7³2'34.87"S \& 11050'54.09"E). Gambar citra satelit site obyek rancang bangun

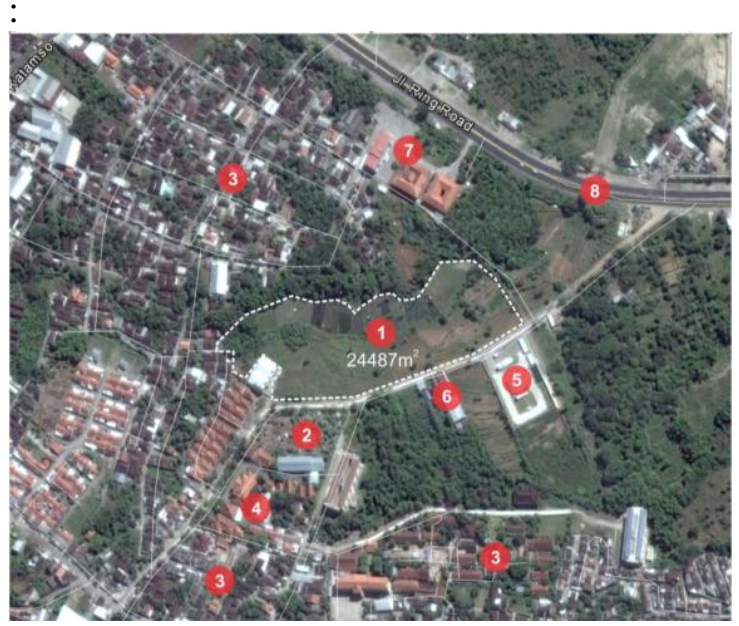

Keterangan : (1) Site obyek rancang bangun, (2) Pemakaman umum, (3) Permukiman, (4) Kantor dinas pemerintahan, (5) Agen spbu, (6) (kemungkinan) gudang \& bengkel las, (7) Asrama akper mamba'ul ulum, dan (8) Jalan ringroad solo utara

Gambar 2. Lokasi site obyek rancang bangun (RKPKP Surakarta 2015, Google Earth, diolah, 2017)

\section{Analisis \& konsep peruangan \& sirkulasi}

\section{Kebutuhan ruang}

Kebutuhan ruang dalam obyek rancang bangun diperoleh berdasarkan aktivitas yang perlu untuk diwadahi (aktivitas dasar hunian), dengan memperhatikan konteks budaya calon penghuni, dan aktivitas lain yang mendukung selama memungkinkan untuk diwadahi dalam obyek rancang bangun, antara lain :

(1) Unit hunian (KM/WC, dapur, ruang jemur privat, kamar tidur, dan ruang serbaguna), (2) Ruang publik / komunal teratapi, (3) Ruang publik / komunal memungkinkan paparan sinar matahari langsung, (4) Ruang parkir alat transportasi, (5) Ruang pertemuan (indoor) warga, (6) Masjid, (7) WC (umum) \& ruang wudhu, (8) Ruang pengelola rusun, (9) Pos keamanan, (10) Halaman dengan perkerasan (khususnya untuk aktivitas olahraga / parkir), (11) Lahan subur (sebagai sarana usaha penghuni (budidaya)), (12) Lapangan (untuk aktivitas komunal), (13) Taman (outdoor), (14) Lahan kosong (letaknya cukup jauh dari aktivitas keseharian penghuni termasuk area hunian untuk kegiatan tertentu yang mungkin mengganggu kenyamanan antar penghuni), (15) Kolam renang anak (bila memungkinkan ada, untuk memberikan daya tarik orang asing datang ke area obyek rancang bangun yang otomatis memungkinkan meningkatkan potensi ekonomi di tempat tersebut), dan (16) Kolam \& area memancing ikan (bila memungkinkan disediakan, sebagai sarana usaha dan rekreasi penghuni).

\section{Program ruang}

Analisis tipe massa hunian dan program ruang didalamnya, didasari pertimbangan : terpenuhinya kebutuhan dan persyaratan tiap ruang, kesederhanaan bentuk, kekuatan struktur berdasarkan bentuk, kualitas pencahayaan \& penghawaan alami maksimal pada tiap ruang, efektivitas luasan bangunan, standar kenyamanan tertentu (kemudahan, keamanan, privasi, kenyamanan visual), dan asumsi biaya konstruksi dan operasional bangunan. Tipe dan program ruang tersebut antara lain :

1. Tipe rumah deret 2 lantai (low rise):

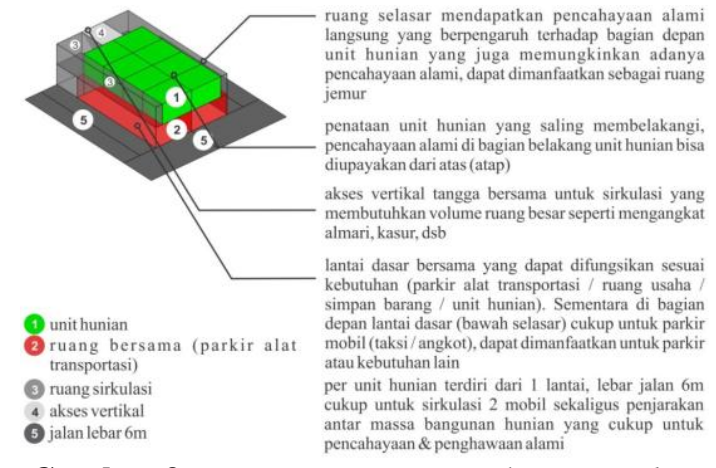

Gambar 3. Program ruang massa bangunan low rise

2. Tipe massa bangunan 3-5 lantai (mid rise) kombinasi 2 tipe berikut : 


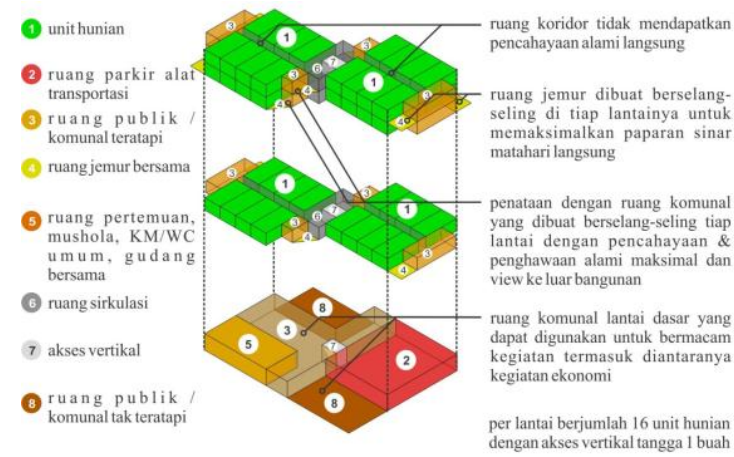

Gambar 4. Program ruang massa bangunan mid rise tipe 1

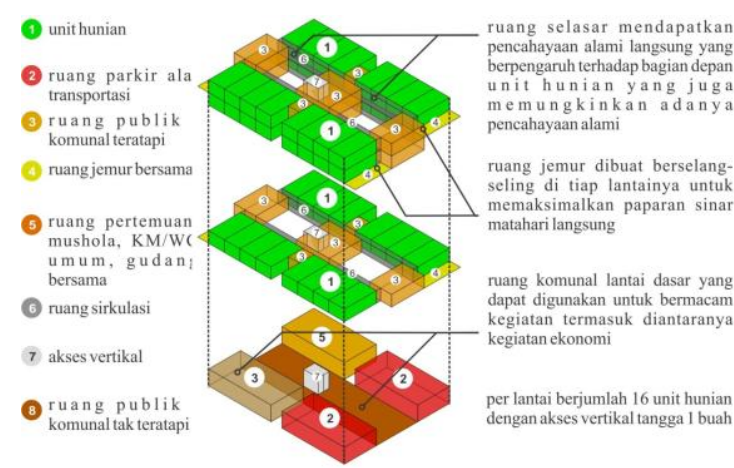

Gambar 5. Program ruang massa bangunan mid rise

3. Tipe massa bangunan $>5$ lantai (high rise) :

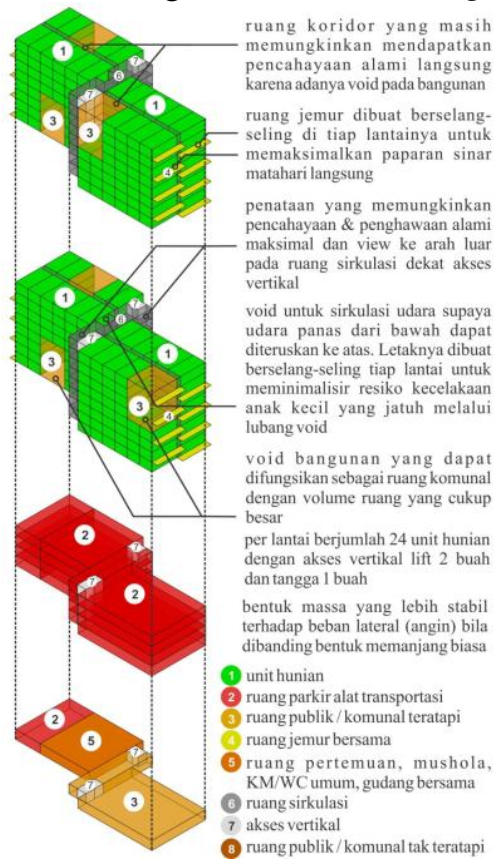

Gambar 6. Program ruang massa bangunan high rise

Bentuk massa bangunan dan program ruang tersebut tidak bersifat mutlak (masih dapat diubah kembali), dan mungkin dilakukan kombinasi antar tipe, atau dibuat bentuk / program ruang baru, menyesuaikan bentuk siteplan. Perubahan yang dilakukan mungkin didasari oleh pertimbangan efektivitas penggunaan lahan, struktur, kenyamanan, biaya konstruksi, estetika, potensi lain, dan analisa yang lebih mendalam pada saat proses perancangan. (Hasil akhir untuk massa hunian tipe mid rise ditetapkan 5 lantai, dan tipe high rise ditetapkan 23 lantai).

Analisis zoning site didasari oleh pertimbangan : pemenuhan kebutuhan \& persyaratan ruang, kondisi eksisting \& potensi site \& lingkungan, solid-void untuk pencahayaan \& penghawaan alami, tidak merugikan lingkungan (warga) sekitar, drainase, kenyamanan, fleksibilitas, dan estetika (proporsi).

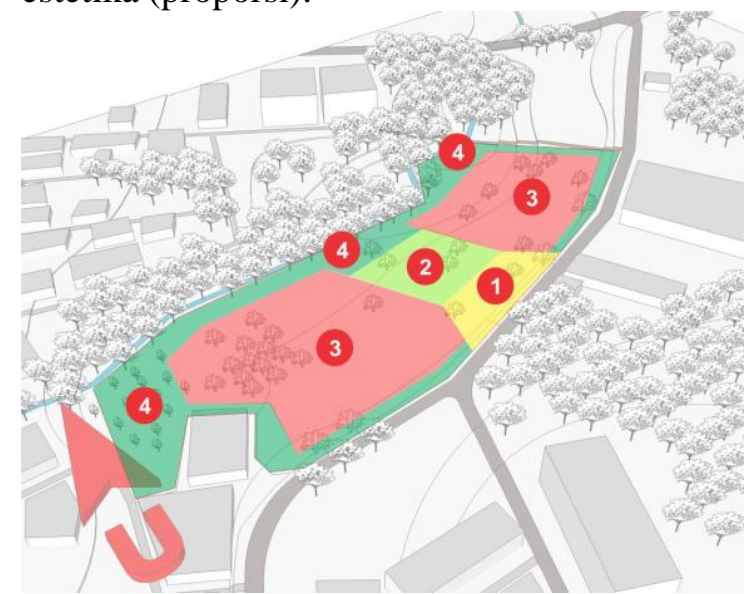

Keterangan : (1) Halaman (ME), (2) Lapangan (berumput), (3) Area hunian, dan (4) Lahan kosong / lahan subur untuk ditanami / area teduh (pohon) / gazebo / taman outdoor (tempat bermain anak) / kolam renang / kolam ikan

Gambar 7. Zoning site

Pengolahan lansekap nantinya juga mempertimbangkan aksesbilitas \& sirkulasi bagi semua user, termasuk aksesbilitas alat transportasi dan sistem utilitas. Pengolahan kembali dan penataan massa bangunan hunian di atas site, dilakukan dengan mempertimbangkan efektivitas \& efisiensi penggunaan lahan terbangun (jumlah unit hunian maksimal, dengan batasan proporsi lansekap dan persyaratan kebutuhan lainnya).

Analisis denah unit hunian didasari pertimbangan : terpenuhinya kebutuhan \& persyaratan ruang hunian (asumsi user 3-4 
orang terdiri dari ayah, ibu, dan 1-2 anak), efektivitas \& efisiensi luasan unit hunian, pendekatan struktur dan dimensi yang sederhana, fleksibilitas, kualitas pencahayaan \& penghawaan alami, kenyamanan (gerak, visual, meminimalisir resiko-resiko yang cenderung tak diinginkan yang mungkin terjadi, dan kesopanan).

1. Denah unit hunian tipe rumah deret 2 lantai (low rise), luas $30,07 \mathrm{~m}^{2}$. Konsep fleksibilitas meliputi : ruang los yang dapat disekat sesuai kebutuhan penghuni, meja dapur portable yang terpisah (kompor, meja saji, dan sink) dapat ditata sesuai kebutuhan penghuni, dan instalasi pemipaan air bersih dan air kotor sink yang tidak disembunyikan dalam dinding untuk mendukung fleksibilitas letak sink dan kemudahan maintenance.

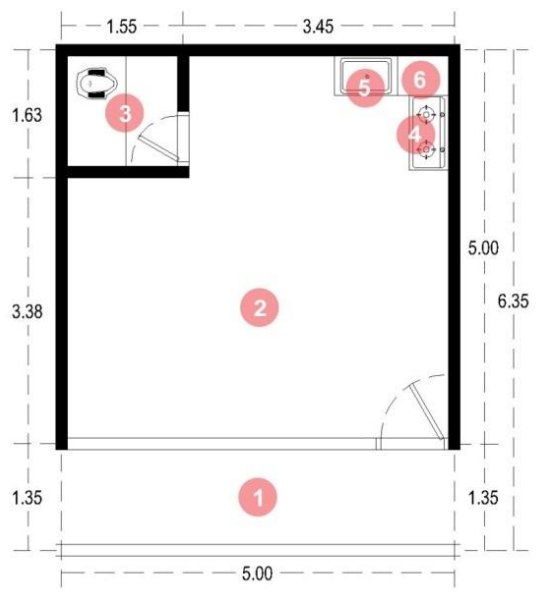

Keterangan : (1) Teras depan / selasar, (2) Ruang los, (3) Kamar mandi, (4) Meja kompor, (5) Sink, dan (5) Meja saji

Gambar 8. Denah unit hunian low rise tipe 1

2. Denah unit hunian tipe 3-5 lantai (mid rise) $\&$ tipe $>5$ lantai (high rise), luas $31,02 \mathrm{~m}^{2}$. Konsep fleksibilitas sama dengan denah tipe di atas, ditambah desain pintu kamar mandi yang memungkinkan adanya alternatif letak pintu (menghadap samping atau belakang) untuk mendukung layout peruangan yang lebih fleksibel. Denah unit hunian dibuat berselangseling tiap lantainya untuk memaksimalkan paparan sinar matahari pada ruang jemur privat, sehingga terdapat 2 tipe denah (lihat Gambar 9).

\section{Struktur dan pemilihan material}

Dasar pertimbangan : kesesuaian struktur dengan bentuk bangunan, kemungkinan ketersediaan teknologi \& tenaga ahli, kekuatan struktur, meminimalisir material yang sulit / tidak terbarukan / tidak dapat di-daur ulang, keawetan / kemudahan perawatan, biaya material \& konstruksi, resiko lain yang mungkin terjadi yang mempengaruhi (kenyamanan) user, fleksibilitas, estetika (selain lower structure).

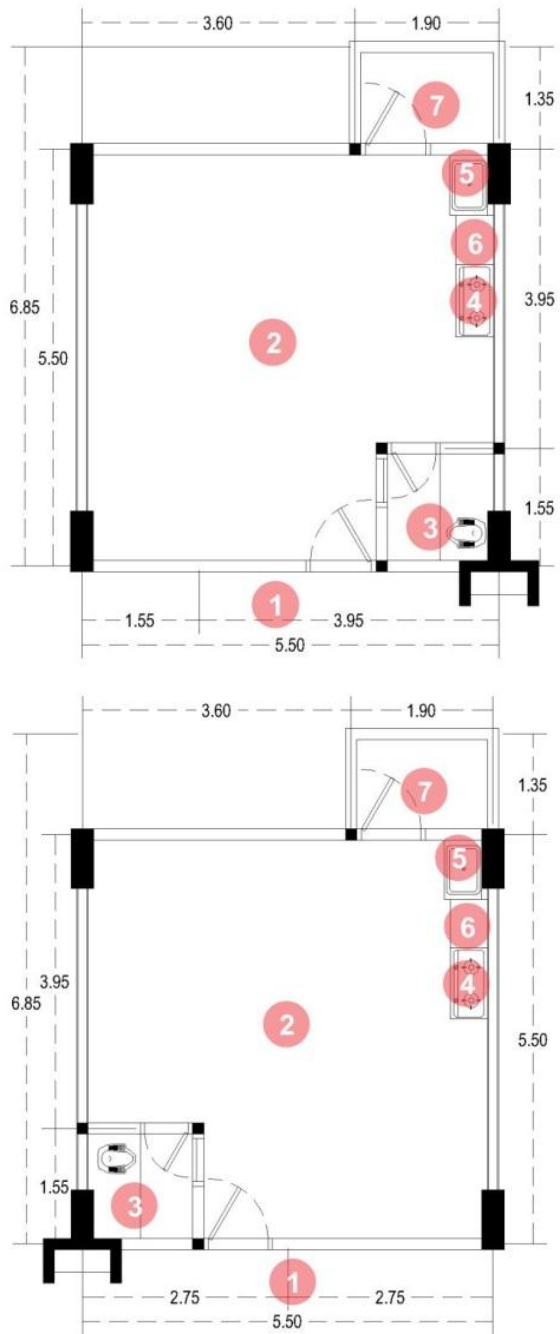

Keterangan : (1) Teras depan / koridor / selasar, (2) Ruang los, (3) Kamar mandi, (4) Meja kompor, (5) Sink, (6) Meja saji, (7) Ruang jemur privat

Gambar 9. Denah unit hunian mid \& high rise tipe 1 (atas) dan tipe 2 (bawah)

\section{Pendekatan lower structure bangunan}

(1) Massa hunian tipe low rise, pos keamanan, ruang pengelola, dan masjid : Karena hanya 2 lantai dan beban bangunan yang tidak terlalu 
besar, maka dipilih pondasi telapak pada tiap kolom struktur dan pondasi menerus batu kali sebagai tumpuan dinding dan penahan tanah; (2) Massa hunian tipe mid rise : Karena beban massa bangunan diprediksi dianggap cukup besar (5 lantai dengan struktur beton bertulang), maka dipilih pondasi bored pile / Caissons; dan (3) Massa hunian tipe high rise: Karena beban massa bangunan diprediksi dianggap besar (23 lantai, struktur beton bertulang), maka dipilih pondasi bored pile / Caissons dan pondasi tikar (bila diperlukan). Semua massa bangunan hunian menggunakan struktur rangka (rigid frame) dan perkuatan struktur core \& shear wall (bila dibutuhkan) untuk massa bangunan hunian high rise

\section{Pendekatan sub structure bangunan}

Semua bangunan (massa hunian, pos keamanan, ruang pengelola, dan masjid) menggunakan kolom \& balok beton bertulang konvensional atau pracetak yang lebih awet (tidak korosif), tahan panas \& api, dan secara kenyamanan visual dianggap lebih cocok untuk fungsi hunian. Sedangkan untuk plat lantai (bangunan $>1$ lantai) menggunakan beton bertulang (pracetak CLC (Cellular Lightweight Concrete) atau semacamnya). Berat material yang ringan mungkin mempengaruhi biaya konstruksi pondasi, namun perlu analisa RAB lebih lanjut. Bila lebih mahal, dipilih plat lantai beton bertulang konvensional. Untuk menambah perkuatan plat lantai ruang parkir pada massa hunian high rise, mengingat lantai pada ruang tersebut mewadahi aktivitas lalu lalang kendaraan bermotor, maka dapat menggunakan struktur waffles slab. Jenis struktur ini memiliki kekuatan (kekakuan) plat lantai yang lebih baik daripada plat lantai biasa.

\section{Pendekatan upper structure bangunan}

Massa hunian tipe low rise, pos keamanan \& ruang pengelola, dan masjid menggunakan atap metal roof rangka baja ringan yang diprediksi lebih awet dan murah. Khusus untuk massa hunian tipe low rise, dikombinasi dengan atap transparan (solartuff atau sejenisnya) untuk memaksimalkan pencahayaan alami di dalam unit hunian. Massa hunian mid \& high rise menggunakan atap dak beton bertulang, sekaligus sebagai lantai penopang rooftank. Bila perlu, pada atap ini mungkin bisa ditambahkan struktur waffle slab untuk menambah kekuatan strukturnya, seperti plat lantai pada ruang parkir massa hunian high rise.

\section{Pemilihan material non-struktur bangunan}

Pasangan batu bata plester aci cat digunakan untuk unit hunian (low \& mid rise), dan dinding ruang lain yang terkena tampias air hujan secara langsung. Pasangan hebel digunakan untuk unit hunian (high rise), dan alternatif dinding pemisah antar unit hunian, bila mampu memberikan privasi suara antar hunian yang lebih baik, dan biaya konstruksi yang tidak terlalu mahal. Pasangan batako semen pc digunakan untuk pagar tembok dan dinding selain unit hunian, yang tidak terkena tampias air hujan secara langsung, serta alternatif dinding unit hunian bila perhitungan analisa RAB lebih lanjut lebih murah dibandingkan dinding batu bata plester aci. Dinding solartuff atau polikarbonat datar digunakan untuk kebutuhan dinding transparan (tembus cahaya). Semua kusen menggunakan aluminium dan PVC (kamar mandi) yang dianggap lebih awet. Semua daun pintu menggunakan panil (multiplek / polikarbonat) + rangka (aluminium) dan PVC (kamar mandi) yang dianggap lebih awet. Jendela kaca (aluminium) digunakan untuk unit hunian, ruang pertemuan (indoor), pos keamanan, dan masjid yang dianggap lebih awet. Roster beton digunakan sebagai bouven (bukaan / anginangin) dan glassblock digunakan untuk kebutuhan dinding tembus cahaya seperti pada core tangga. Boven aluminium kaca dan jalusi untuk unit hunian mid \& high rise. Keramik warna putih digunakan untuk bagian dalam unit hunian yang berkesan bersih dan luas. Lantai ubin atau plester aci digunakan untuk teras, selasar, koridor, dan ruang bersama di lantai atas yang relatif murah. Lantai plester semen aci digunakan untuk ruang komunal dan parkir yang dianggap efisien. Beton bertulang digunakan untuk tangga bersama (interior \& outdoor). Rangka besi cat + wiremesh digunakan untuk pembatas selasar dan void yang ringan dan relatif murah. Tembok (batako semen pc) digunakan untuk pembatas 
atap datar dan selasar mid rise yang lebih kokoh dibanding pagar besi untuk tujuan keamanan. Rangka besi pipa susun vertikal finish cat digunakan untuk pembatas ruang komunal dan ruang jemur mid \& high rise yang kuat, berkesan terbuka, dan relatif aman bagi anak kecil. Diameter pipa dipilih yang cukup kuat disusun vertikal setinggi $3 \mathrm{~m}$ tanpa perkuatan horisontal. Plafond PVC flat doff putih dikombinasikan dengan polikarbonat digunakan untuk plafond unit hunian low rise di lantai 2, masjid dan interior pos keamanan (semua unit hunian selain low rise lantai 2. Semua kamar mandi tanpa plafond.

\section{Pendekatan struktur dan pemilihan material lansekap}

Struktur penahan tanah menggunakan struktur talud batukali yang umum digunakan. Material paving beton digunakan untuk permukaan jalan karena dianggap cenderung kecil kemungkinan terjadi becek, lebih bersih (daripada grassblock), dan plester semen aci untuk halaman. Saluran sanitasi \& drainase menggunakan material beton pracetak tertutup atau pracetak terbuka, dengan penutup plat beton untuk area dekat hunian, area komunal / parkir lantai dasar dalam bangunan, untuk mengurangi kesan kotor dan polusi bau yang mungkin muncul. Beton pracetak terbuka dengan penutup grill besi digunakan untuk keliling halaman (dengan perkerasan), untuk mempercepat aliran air pada permukaan halaman masuk ke dalam saluran. Beton pracetak terbuka untuk area selain yang disebutkan di atas.

\section{Sistem utilitas}

\section{Sistem air bersih}

Semua alternatif sumber air bersih dipilih dengan sistem jaringan air bersih seperti berikut :

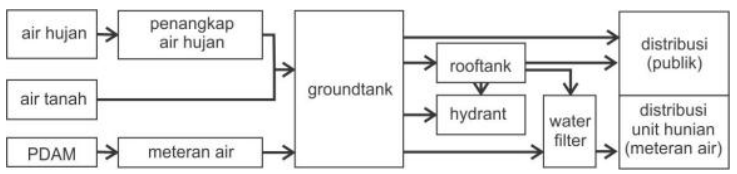

Bagan 1. Bagan sistem jaringan air bersih

Sumber air bersih air tanah dan air hujan mejadi sumber prioritas pertama. Ketika musim penghujan menggunakan air tanah, sementara air hujan ditampung. Ketika musim kemarau menggunakan air hujan yang sudah ditampung. (Keputusan tersebut berlaku bila volume air di lokasi tersebut memang mencukupi, maka akan lebih baik bila ada analisis lapangan lebih detail terlebih dahulu, mengenai perbandingan volume air rata-rata yang dibutuhkan oleh pengguna dalam obyek rancang bangun, dengan volume air tanah \& air hujan yang dapat ditampung setiap tahunnya (setiap musim)). Sumber air PDAM menjadi sumber air cadangan, ketika volume air tanah dan air hujan yang ditampung tidak mampu mengakomodir kebutuhan penghuni. Semua sumber air bersih ditampung dalam satu penampungan awal (groundtank), melewati proses pengolahan air bersih (water filter) sebelum didistribusikan ke semua unit hunian, dengan tujuan air bersih yang dihasilkan nanti memiliki kualitas yang layak untuk dikonsumsi (tidak harus siap minum). Pajak air bersih dari air tanah \& air hujan yang ditetapkan oleh pengelola, diasumsikan sama dengan pajak air bersih dari PDAM. Mudahnya, biaya yang dibebankan kepada penghuni nanti seharga pajak air bersih PDAM + biaya operasional water filter, dan dihitung menurut volume air yang digunakan. Atap datar pada massa bangunan hunian mid \& high rise sekaligus menjadi area tangkapan air hujan. Air hujan yang jatuh pada atap mengalir menuju lubang saluran air hujan di sekeliling atap lalu dialirkan menuju groundtank. Bila luasan atap datar dianggap kurang mampu menangkap air hujan secara maksimal, dapat ditambahkan instalasi penangkap air hujan tambahan yang diletakkan di beberapa titik lokasi di dalam site. Pipa saluran menggunakan material pipa PVC. Instalasi pipa air bersih dalam bangunan tidak ada yang disembunyikan ke dalam dinding atau lantai, untuk mempermudah pengecekan dan maintenance instalasi tersebut.

\section{Sistem pembuangan air limbah (air kotor, tinja, dan air hujan)}

Sistem pembuangan greywater menggunakan sumur resapan + bak pemisah lemak. Instalasi akar wangi juga disediakan sebagai alternatif pengolahan air kotor, bila volume sumur resapan tidak mampu menampung volume greywater yang ada. Sistem pembuangan tinja 
cukup menggunakan septictank konvensional atau bioseptic tank bila harga instalasinya lebih murah dibanding konvensional. Pipa saluran air kotor dan air tinja dalam bangunan menggunakan material pipa PVC. Tidak ada pipa yang disembunyikan ke dalam dinding atau lantai untuk kemudahan perawatan.

\section{Sistem elektrikal (listrik \& antena TV)}

Bagan sistem elektrikal secara garis besar :

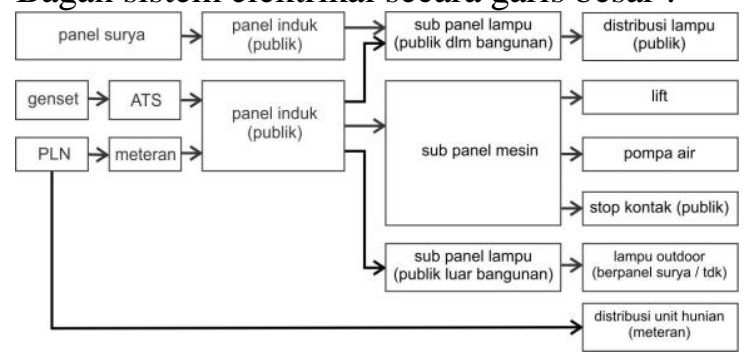

Bagan 2. Bagan sistem eletrikal

Sumber listrik PLN digunakan untuk kebutuhan listrik unit hunian, lift, dan pompa air. Sumber listrik panel surya digunakan untuk kebutuhan lampu penerangan pada ruang bersama (massa bangunan hunian mid \& high rise) dan lampu penerangan outdoor. Jenis lampu penerangan outdoor yang terkena paparan cahaya matahari langsung dipilih jenis lampu yang sudah dilengkapi dengan panel surya. Bila daya yang dihasilkan panel surya mampu mencukupi kebutuhan daya listrik untuk pompa air, dipilih sumber listrik tersebut. Sumber listrik genset digunakan untuk kebutuhan listrik lift dan pompa air pada kondisi darurat (arus listrik PLN padam). Kabel listrik pada lansekap diupayakan ditanam di dalam tanah untuk tujuan kerapian. Sementara untuk Antena TV bersama / kelompok digunakan pada massa bangunan hunian high rise sedangkan massa hunian low $\&$ mid rise diupayakan pribadi oleh penghuni.

\section{Sistem persampahan}

Biopori selain sebagai resapan air hujan ke dalam tanah, juga digunakan sebagai alternatif tempat pembuangan sampah berupa seresah daun dan sampah organik yang ada di lingkungan obyek rancang bangun. Sampah ini mungkin bisa dimanfaatkan sebagai kompos. Semua sampah di tampung pada TPS dalam obyek rancang bangun, yang nantinya ada petugas DKP yang akan mengambil sampah tersebut untuk selanjutnya dibuang ke TPA terdekat.

\section{Sistem pemadam kebakaran}

Sistem pemadam kebakaran menggunakan hydrant. Untuk massa bangunan hunian low rise, hydrant diletakkan di luar dekat bangunan, sementara pada massa bangunan hunian mid \& high rise diletakkan pada lokasi strategis dalam massa bangunan, lengkap dengan tabung pemadam kebakaran dan di luar dekat bangunan. Sprinkler dan detektor kebakaran diaplikasikan untuk massa hunian mid \& high rise.

\section{Sistem penangkal petir}

Penangkal petir dipasang terutama pada massa bangunan hunian high rise yang mungkin mampu melindungi area di sekitarnya.

Berdasarkan analisis \& konsep di atas, didapatkan hasil rancangan seperti berikut :

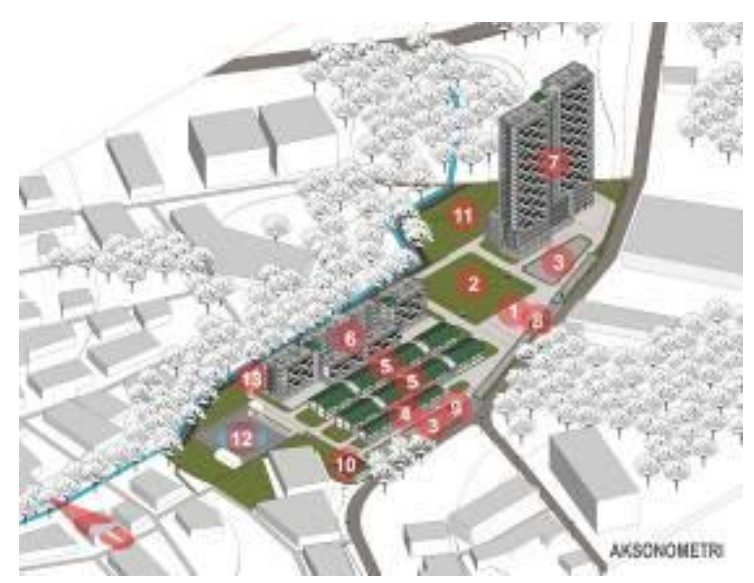

Keterangan : (1) Halaman berpaving, (2) Tanah lapang, (3) Halaman dengan perkerasan (plester semen aci), (4) Massa hunian low rise 1, (5) Massa hunian low rise 2, (6) Massa hunian mid rise, (7) Massa hunian high rise, (8) Pos keamanan \& ruang pengelola, (9) Pos keamanan, (10) Masjid, (11) Lahan kosong (lahan budidaya atau dimanfaatkan untuk kebutuhan lain), (12) Kolam renang anak, dan (13) Ruang genset (untuk massa hunian mid rise)

Gambar 10. Aksonometri obyek rancang bangun Berikut adalah gambar-gambar yang menunjukkan ruang-ruang yang memiliki potensi ekonomi di dalam obyek rancang bangun (lihat Gambar 11-15) : 


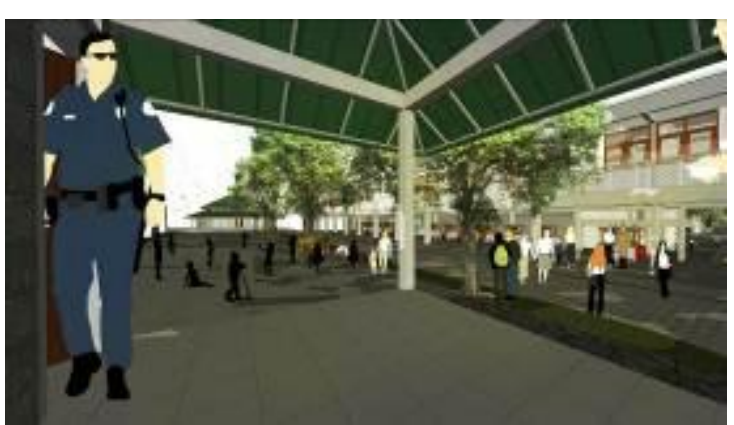

Gambar 11. Perspektif suasana ruang komunal dekat pos keamanan di side entrance

Pada gambar di atas nampak pula kondisi ruang di lantai 1 massa hunian low rise tipe 1 yang dapat dimanfaatkan sebagai ruang usaha selain sebagai ruang parkir penghuni.

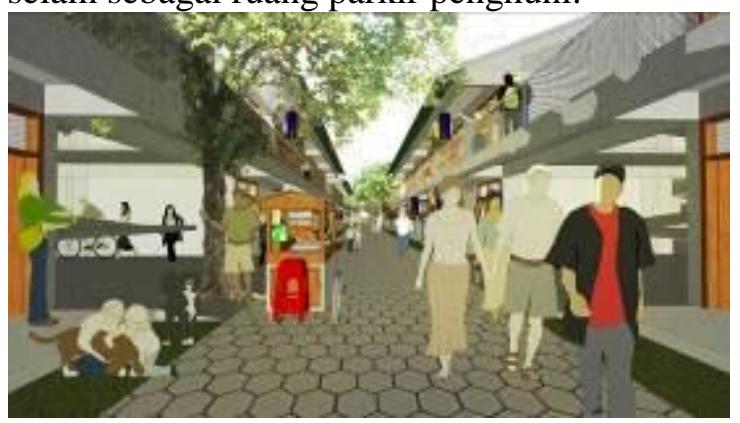

Gambar 12. Perspektif suasana di area massa hunian low rise tipe 2

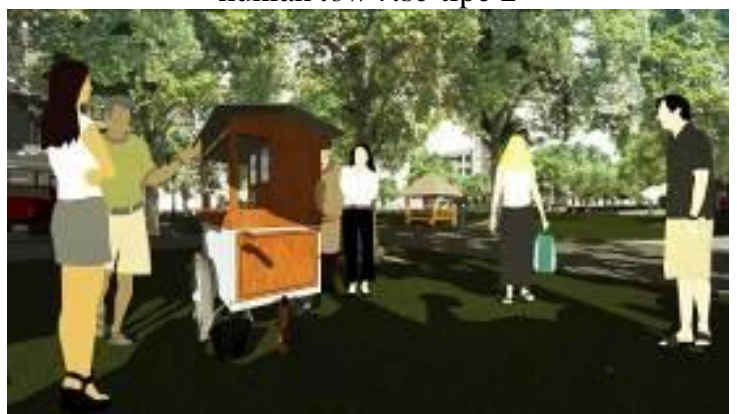

Gambar 13. Perspektif suasana ruang komunal dekat tanah lapang

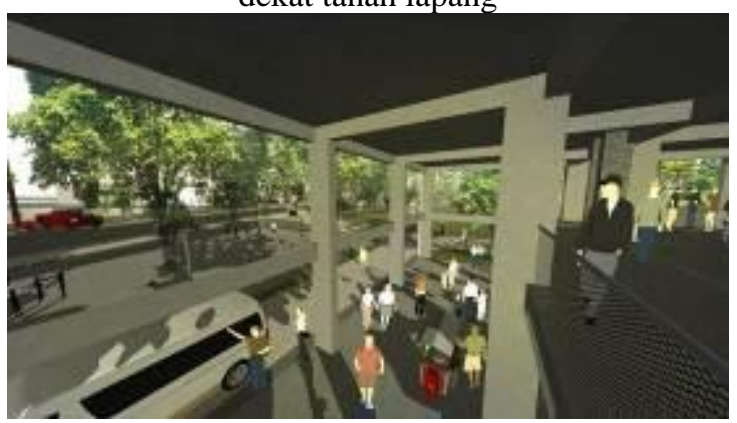

Gambar 14. Perspektif suasana ruang komunal di dalam massa hunian high rise lantai $1 \& 2$, serta ruang komunal di depan bangunan ini

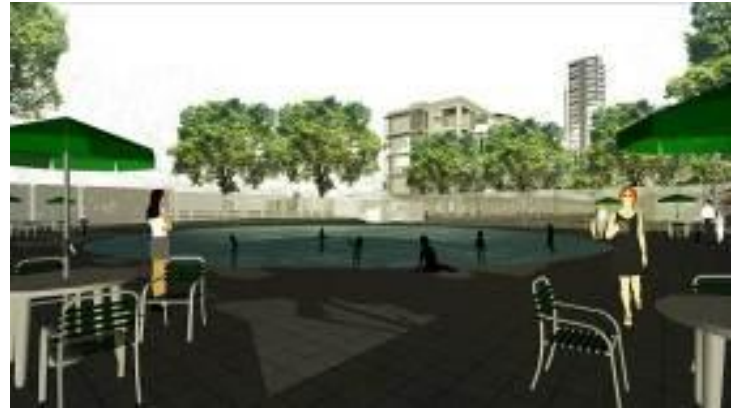

Gambar 15. Perspektif suasana kolam renang anak

Berikut adalah alternatif layout unit hunian massa hunian tipe low rise (lihat Gambar 16 dan 17). Keterangan : (1) Teras / selasar, (2) Ruang serbaguna, (3) Kamar tidur, (4) Dapur, dan (5) Kamar mandi / WC.

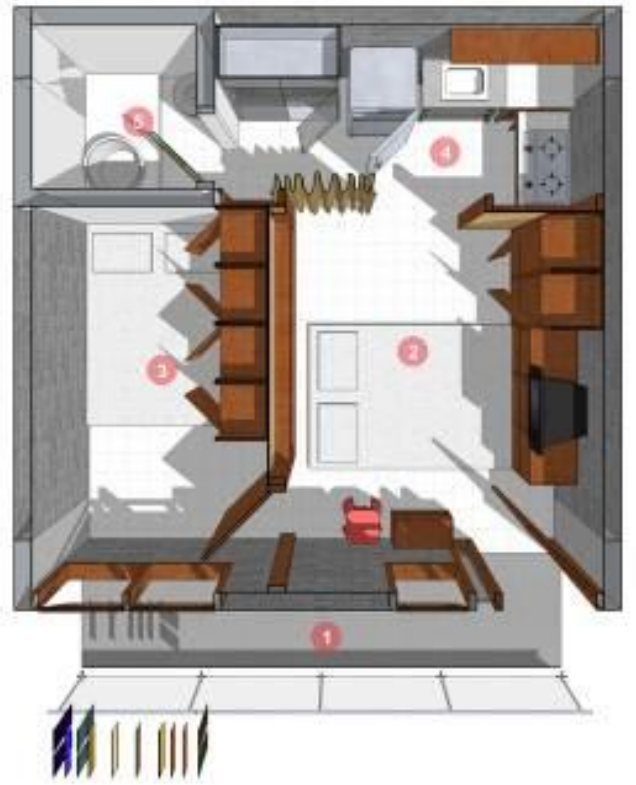

Gambar 16. Layout unit hunian low rise alternatif 1 (1 kamar tidur) 


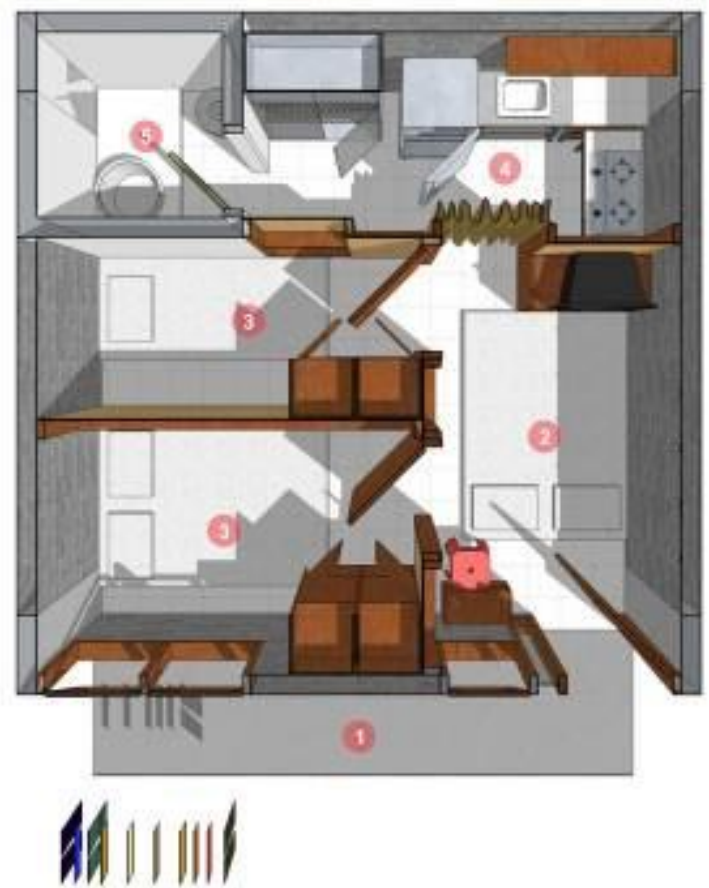

Gambar 17. Layout unit hunian low rise alternatif 2 (2 kamar tidur)

Berikut adalah gambar salah satu contoh penerapan konsep fleksibilitas yang diaplikasikan pada desain meja sink yang dibuat portable, supaya mampu beradaptasi dengan layout hunian yang berbeda menyesuaikan kebutuhan penghuni, yang mungkin berbeda satu dengan yang lain (lihat Gambar 18). Prinsip yang sama juga diaplikasikan pada meja kompor dan meja saji.

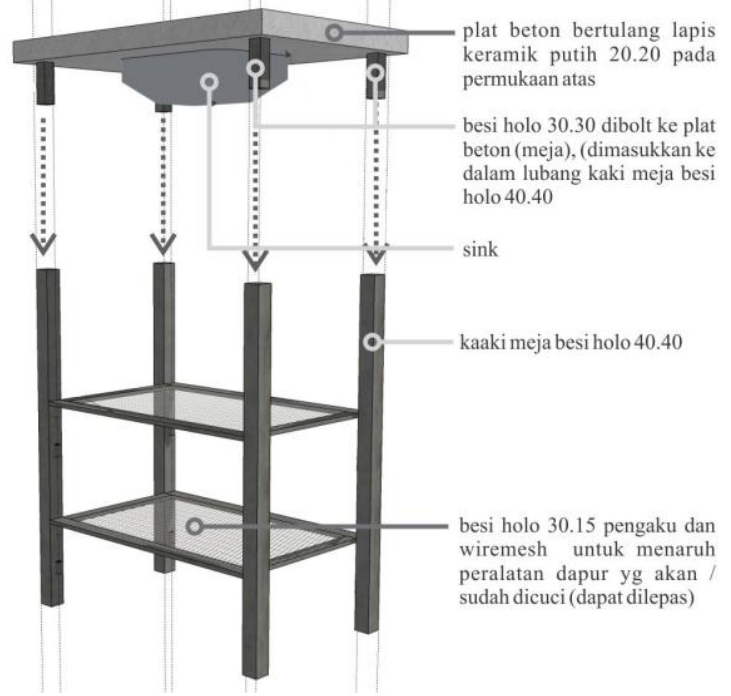

Gambar 18. Detail desain meja sink pada tiap unit hunian
Berikut adalah gambar contoh pengaplikasian material bangunan dalam obyek rancang bangun, yaitu unit hunian tipe mid \& high rise (lihat Gambar 19 dan 20) :

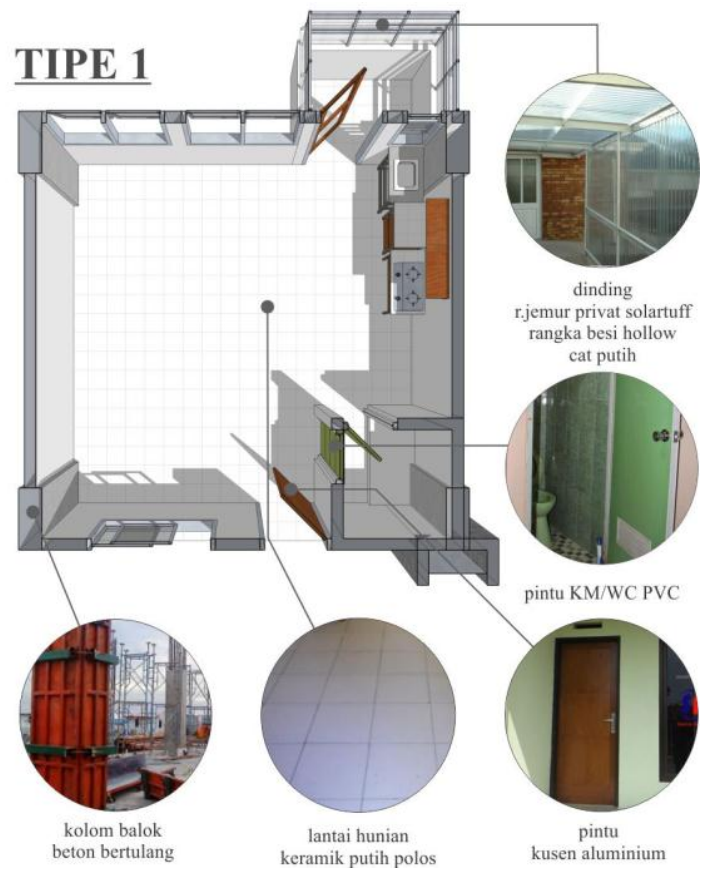

Gambar 19. Gambar konsep denah dan material unit hunian mid \& high rise tipe 1

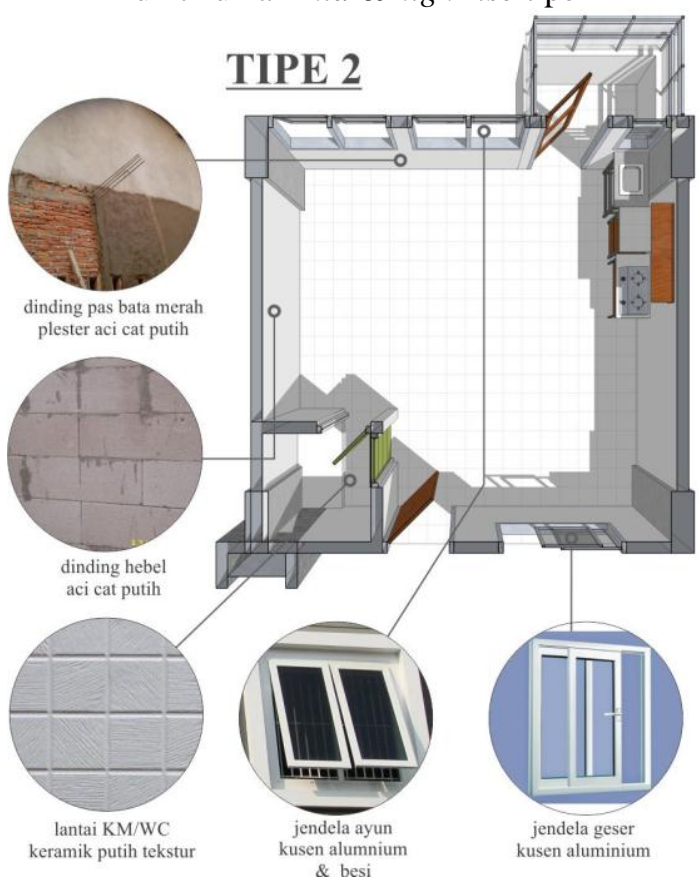

Gambar 20. Gambar konsep denah dan material unit hunian mid \& high rise tipe 2 


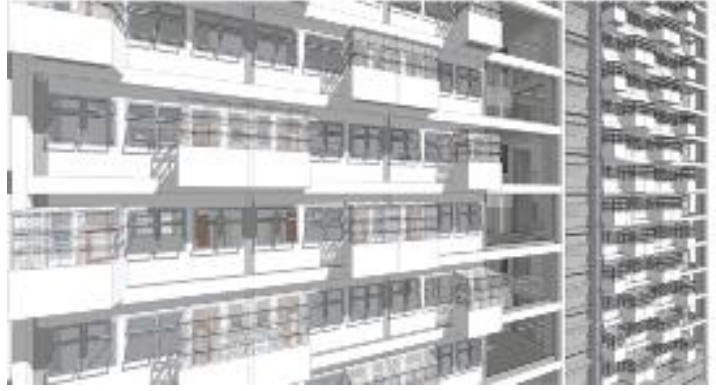

Gambar 21. Gambar konsep fasad massa hunian mid \& high rise yang memperlihatkan penataan unit hunian yang berselang-seling untuk memaksimalkan pencahayaan alami ke dalam ruang jemur privat (Ananditya, 2017)

Gambar berikut merupakan contoh alternatif layout unit hunian mid \& high rise tipe 1. Untuk alternatif layout unit hunian tipe 2 memiliki bentuk yang hampir sama. Dari contoh layout di bawah ini terlihat perbedaan letak pintu kamar mandi pada layout alternatif 3. (lihat Gambar 22-24). Keterangan : (1) Koridor / selasar, (2) Ruang serbaguna, (3) Kamar tidur, (4) Dapur, (5) Kamar mandi / WC, dan (6) Ruang jemur privat.

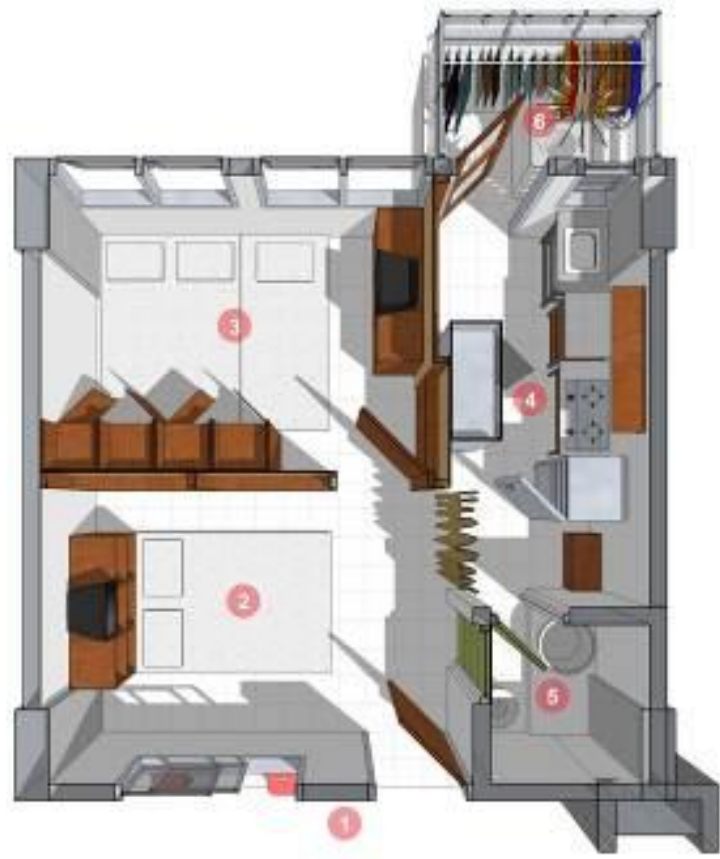

Gambar 22. Layout unit hunian mid \& high rise tipe 1 alternatif 1 (1 kamar tidur, dapur dan ruang serbaguna terpisah)

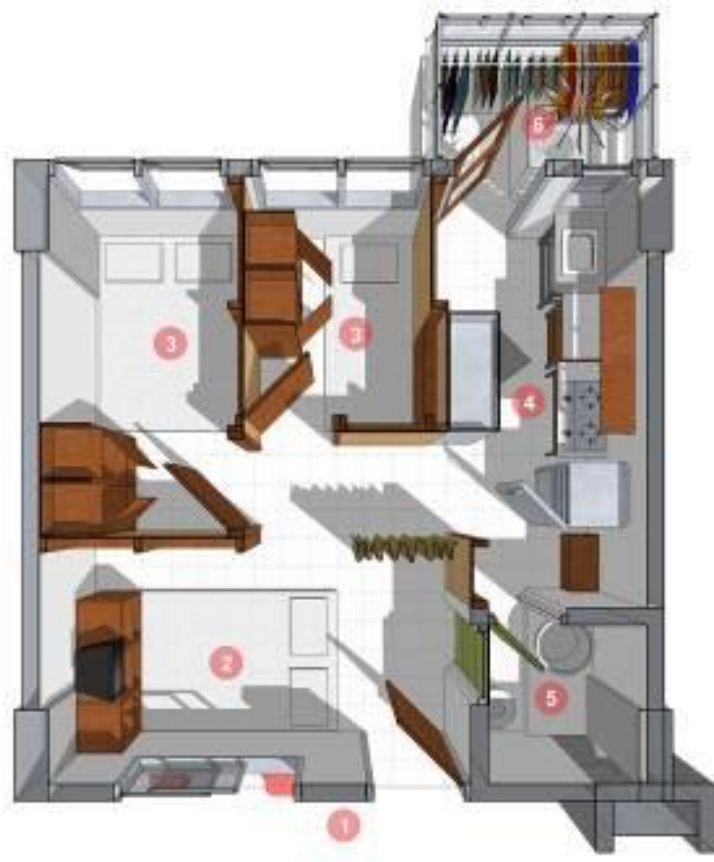

Gambar 23. Layout unit hunian mid \& high rise tipe 1 alternatif 2 (2 kamar tidur, dapur dan ruang serbaguna terpisah) (Ananditya, 2017)

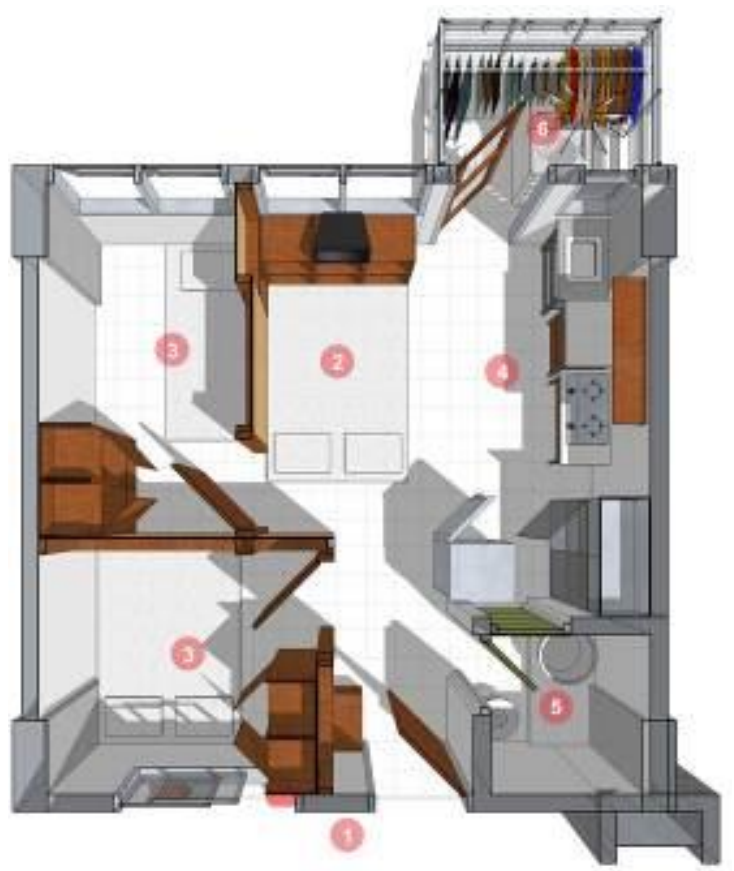

Gambar 24. Layout unit hunian mid \& high rise tipe 1 alternatif 3 (2 kamar tidur, dapur dan ruang serbaguna menyatu)

\section{KESIMPULAN}

Setelah perancang melakukan proses perancangan obyek rancang bangun, Rusunawa di Surakarta dengan pendekatan 
Arsitektur Berkelanjutan, ada beberapa hal yang dapat disimpulkan menurut subyektifitas perancang, antara lain : (1) hal mendasar yang perlu dilakukan dalam merancang obyek rancang bangun sejenis (mungkin sama dengan obyek dengan fungsi yang berbeda) adalah memahami konteks user (pengguna obyek rancang bangun), termasuk hal apa saja yang menjadi kebutuhan mereka, dan memahami kondisi site \& lingkungan yang ada, lalu bagaimana menyikapinya (mengambil keputusan desain yang terbaik). Dalam proses perancangan, perancang terkendala pada eksplorasi data yang valid dan pemahaman yang lebih dalam tentang calon penghuni, sehingga selama proses perancangan banyak yang hanya mengandalkan pendekatan asumsi (logika) pribadi; (2) Aspek ekonomi adalah aspek yang cukup sulit (dan mungkin cukup sensitif) untuk dianalisa, terutama pada pertimbangan harga material \& konstruksi bangunan, (3) Pendekatan Arsitektur Berkelanjutan dianggap cocok digunakan dalam merancang obyek rancang bangun dengan fungsi semacam ini, dimana aspek estetika tidak terlalu menjadi prioritas penting untuk dipertimbangkan.

\section{REFERENSI}

Aulya, Fida Hasna Karimah. (2016). Kepaksian Pernong Skala Brak sebagai Kawasan Wisata Budaya di Lampung Barat. Unpublished undergraduate thesis, Universitas Sebelas Maret, Surakarta.

Frick, Heinz dan Tri Hesti Mulyani. 2006. Arsitektur Ekologis. Yogyakarta : Kanisius

Kusumo, Adi Surya. (2015) .Bamboo Foundation di Boyolali dengan Pendekatan Sustainable Asritektur. Unpublished undergraduate thesis, Universitas Sebelas Maret, Surakarta

Putra, Citra Dwi. (2009). Rumah Susun Sederhana Sewa di Surakarta dengan Penekanan pada Ruang Bersama dengan Pendekatan Arsitektur Perilaku.Unpublished undergraduate thesis, Universitas Sebelas Maret, Surakarta
Rencana Kawasan Permukiman Kumuh Perkotaan Kota Surakarta Tahun 2015

Sari, Febrina Madya. (2012). Pondok Sejahtera Anak Nusantara di Surakarta sebagai Wadah Kegiatan Pemberdayaan Anak Jalanan melalui Pendekatan Arsitektur Perilaku. Unpublished undergraduate thesis, Universitas Sebelas Maret, Surakarta

Sumardjito. Modul ajar MK utilitas FT UNY 